\section{Principle of Liberty or Harm Principle?}

\author{
Paola Cavalieri \\ Etica \& Animali \\ Milan
}

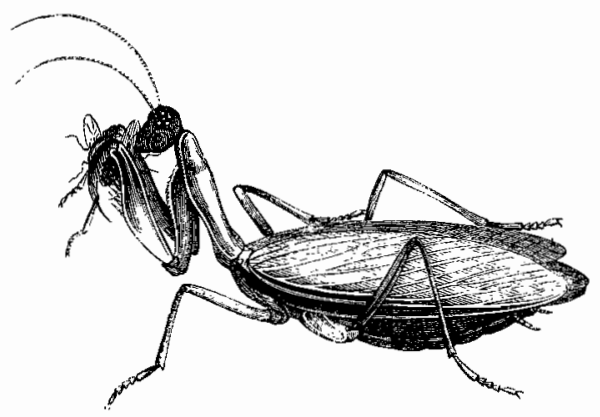

In the framework of Western democracies, the movement for the prevention of cruelty to animals has been seen, ever since it dawned, as a lobby-a pressure group born to defend some spiritual inclinations, or subsidiary preferences, of some members of the political community. In the first case, the most suitable comparison is with a religious sect, or with a moralizing organization; in the second one, with some association of a more or less corporate nature. Still now, every time an opportunity for debate arises, people take care to present "impartially" the relevant views; here the animals' advocates, there the butchers, the furriers, the experimenters. In the democratic game, every lobby must get its due.

This does not happen by accident. There is in our societies a particular class of criminal actions called "morals offenses." It has been noticed ${ }^{1}$ that, since murder, e. g., is also an offense against morals, such a definition cannot be interpreted but in a restrictive sense, and that "morals offenses" are therefore only those crimes which impair nothing but morals. In fact, it is to the absence of an injured party that the other relevant expression, "victimless crimes," is related. Adultery, sodomy, incest and prostitution are the main examples;

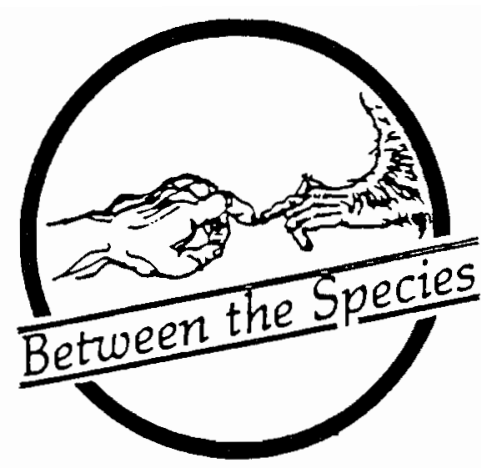

yet, the class also includes nonsexual offenses. One of these is cruelty to animals.

The view that the rationale of the law could be, in addition to the protection of one individual from another, also the punishment of "moral wickedness", has been called "legal moralism." Henceforth, I shall use the term "morality" to refer to the corpus of beliefs and customs that are allegedly impaired by the "victimless crimes" and that legal moralism aims to defend; and the term "morals" to mean what is covered by the laws intended to protect one individual from another. In this sense, rape can be defined as a crime against morals, while homosexual relations between consenting adults can be-and often is-considered a crime against morality. Legal moralism, usually endorsed by conservatives, is criticized by liberals. The view that it may be possible to defend by legal, or else social, sanctions the conformity to a particular code of behavior that is shared by the majority at a certain time seems unacceptable to those for whom the memory of the Inquisition is raised by the contemporary revival of religious fanaticism.

Thus, if the crimes against animals fall within the victimless crimes, i. e., the crimes against morality, the reaction against the movement for the defense of animals becomes explainable. The tolerance of the lobby is acceptable, or better, right, in a liberal society. If, however, the new sect becomes too aggressive, and

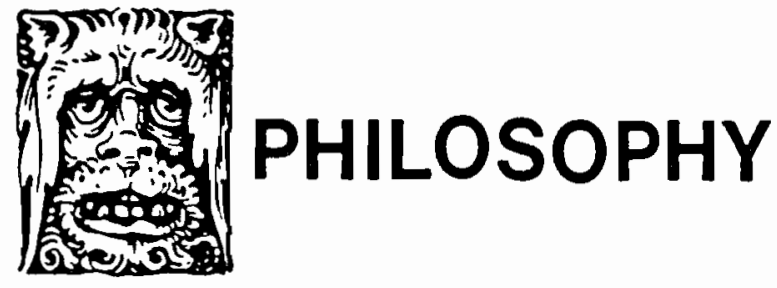


tries to enforce its positions through argued personal and political requests and, if possible, also through the law, the charge of legal moralism, or rather, of Khomeinism (where the term is to be understood as: the highest conceivable level of zealotry) makes a sudden appearance. Those who champion the cause of animals would therefore be reactionary, while those who defend the status quo would be progressive; and those who require, e. g., that we stop eating meat are comparable to the followers of a religious creed who ask for the abolition of every other religion, or to orthodox heterosexuals who ask for the prohibition of homosexual relations.

The argument seems plausible, but it isn't. In fact, it begs the question-it assumes just what it should demonstrate. That the crimes against animals are equivalent to the crimes against morality, that they are in fact crimes against morality, must be argued. One cannot simply assume it, let alone rely upon the fact that it is so according to the laws in force. The existence of societies which condemn association between white and colored people as immoral and punish it by law still leaves the question to be argued; as it has been emphasized, this is where the argument begins, not where it ends. ${ }^{3}$

It is therefore worth surveying the shared framework of the defenders of the status quo. The very concept of victimless crimes clearly reveals that such a definition makes sense only in connection with the idea that, paradigmatically, crimes have victims. The charge of zealotry presupposes a view which is quite familiar to liberal theory and is usually associated with the so-called "Mill's principle." 4 So, by choosing as a ground for discussion this middle-level principle-which is compatible with different substantive positions-not only do we not start from debatable premises, but in fact we resort to an ad hominem argument.

Mill's principle, expounded and justified in the short treatise On Liberty, is, so to speak, a two-sided coin. Toward the end of the volume Mill summarizes in two maxims: "(These) maxims are, first, that the individual is not accountable to society for his actions, in so far as these concern the interests of no person but himself. Advice, instruction, persuasion, and avoidance by other people if though necessary by them for their own good, are the only measures by which society can justifiably express its dislike or disapprobation of his conduct. Secondly, that for such actions as are prejudicial to the interests of others, the individual is accountable, and may be subjected either to social or to legal punishment, if society is of opinion that the one or the other is requisite for its protection." 5 These two sides of the coin originated the two denominations which are used for the principle: principle of liberty (and not of tolerance, as some are paternalistically prone to say), and harm-to-others principle.

On Liberty raised countless discussions. There have been, of course, radical critics who rejected the very principle, either by arguing that there are good reasons for compelling conformity to social morality and for punishing diversions from it even when these do not involve harm to others or by maintaining that since "no man is an island," it is practically impossible to identify classes of action which harm no one but the individual who performs them. Yet, the debate concentrated to a considerable degree on clarification and specification. Besides, those who accepted the principle on its general terms usually focused their attention on the second side of the coin, since the area of the first one, ruled by principle of liberty, coincides with the space that the harm principle does not cover, and expands or narrows according to the interpretations of the latter.

" $(T)$ he only purpose for which power can be rightfully exercised over any member of a civilized community, against his will, is to prevent harm to others." ${ }^{\text {O }}$ Of this concise formulation, in which Mill summed up the harm principle, there are in particular two elements that lend themselves to analysis: the concept of "harm" and the concept of "others." As to what should be meant by "harm," the discussion was lively; apart from the basic distinction between private and public harm, the concept has been qualified in quite different ways as for its extension, and has included, among other notions, the ones of hurt, offense and nonbenefit. In contrast, the concept of "others" received less attention. The other has long been taken for granted-"other" was, generically, every human being. Apart from the issue of paternalistic intervention, where the individual who would be protected is the same that causes the harm, and which is the main target for Mill's darts ("Over himself, over his own body and mind, the individual is sovereign"7), the question of the recipient of the harm has not been regarded as especially relevant till not long ago. Recently, however, the importance acquired by a particular ethical dispute has brought it to the forefront. 
In Practical Ethics, Peter Singer writes:

Mill's view is often and properly quoted in support of the repeal of laws that create "victimless crimes"--like the laws prohibiting homosexual relations between consenting adults, the use of marijuana and other drugs, prostitution, gambling and so on. Abortion is often included in this list.... Those who consider abortion a victimless crime say that, while everyone is entitled to hold and act on her own view about the morality of abortion, no section of the community should try to force others to adhere to its own particular view. In a pluralist society, we should tolerate others with different moral views and leave the decision to have an abortion up to the woman concerned. The fallacy involved in numbering abortion among victimless crimes should be obvious. The dispute about abortion is, largely, a dispute about whether or not abortion does have a 'victim' '...To use [Mill's] principle as a means of avoiding the difficulties of resolving the ethical dispute over abortion is to take it for granted that abortion does not harm an 'other'-which is precisely the point that needs to be proven before we can legitimately apply the principle to the case of abortion." 8

As far as abortion is concerned, this idea is shared by almost all moral philosophers, who therefore focus their attention on the moral status of the fetus. But let us try to substitute the issue, e. g., of the rightness of meat-eating for the rightness of abortion, and the subject "nonhuman animals" for the subject "fetus," and we shall realize that the problem is the same. The fact that most people do not take it into consideration doesn't modify the situation. It is true that throughout our cultural history the "animal question" has been rarely put forward and even more rarely, if ever, taken seriously. But from the beginning of the Seventies, the ethical reflection which has given rise to the corpus of the philosophy of animal liberation has radically changed the situation, as it has challenged the assumption that the factual differences between us and the other animals can automatically be turned into moral inequalities, and thus into a difference in treatment. ${ }^{9}$ Today, simply saying that when animals arc concerned, one should not try to force others to follow one's own view of morality, is no longer possible. Before taking any position we must set, and seriously face, the problem of the moral status of nonhumans.

The resistances which such an approach come up against are remarkable. The tendency to merely neglect the members of other species is so deep-rooted in us that even John Stuart Mill, who as a utilitarian defended the view that animals are part of the moral community to a degree, ${ }^{10}$ is not free from it. And this even in $O n$ Liberty. In fact, while discussing liberty in the religious sphere, he cites, as a case among others, the prohibition against eating pork in force among Mussulmans; and, as he considers whether it be acceptable to forbid nonMussulmans as well to consume it within the borders of an Islamic country, he concludes: "The only tenable ground of condemnation would be, that with the personal tastes and self-regarding concerns of individuals the public has no business to interfere." 11 The problem of the possible violation of the interests of the animals raised for food is not even taken into consideration, and the question seems to be tackled exactly on the terms till now submitted to criticism.

The case of Mill is surprising because it is contradictory. Other cases are so on different grounds. In that semblance of a trial against Rumanian dictator Nicolae Ceausescu the proceedings of which were divulged by the press all over the world, the man who plays the part of the prosecutor enumerates to the accused his crimes against the people: among the major charges there is the fact that, under his regime, the people could not eat meat. The complete moral irrelevance of those who are not human is so natural that, at the very beginning of a revolution against an absolute power, the possibility of wielding the most absolute power over animals is vindicated as an infringed right.

We are still far from the moment when these events will bewilder the general public. However, I believe that the arguments in favor of the inclusion of animals in the sphere of moral equality are stronger than the traditional arguments in favor of their exclusion, and that, if the field of discussion remains that of rational ethics, sooner or later we shall have to acknowledge that animals are "others"- that in their case differences cannot be mechanically turned into inequalities. Should it so happen, we shall also admit that, when relations with nonhumans are involved, we are on the "protective" side of the coin-the one that is covered 
by the harm-principle, and not the one covered by the principle of liberty.

This way would follow the direction of ethical progress as it is conceived by William E. H. Lecky when he describes the moral community as an expanding circle, which embraces first the family, then a class, then a nation, then all humanity, and finally the animal world. ${ }^{12}$ Lecky himself gives a particularly significant example of the changes which have already occurred: "The gladiatorial games form, indeed, the one feature of Roman society which to a modern mind is almost inconceivable in its atrocity. That not only men, but women, in an advanced period of civilization-men and women who not only professed, but very frequently acted upon a high code of morals-should have made the carnage of men their habitual amusement, that all this should have continued for centuries, with scarcely a protest, is one of the most startling facts in moral history." 13 I do not think it necessary to develop the analogy further.

\section{Notes}

${ }^{1}$ See Joel Feinberg, Social Philosophy (Englewood Cliffs: Prentice-Hall, 1973), p. 37.

${ }^{2}$ H. L. A. Hart, Law, Liberty and Morality (Oxford: Oxford University Press, $1986^{8}$ (1963)), pp. 33-34.

${ }^{3}$ Ibid., p. 18.

${ }^{4}$ James Rachels points out that the paternity of the principle is to be ascribed to Jeremy Bentham. See James Rachels, The End of Life (Oxford: Oxford University Press, 1986), p. 180.

${ }^{5}$ John Stuart Mill, On Liberty, in Collected Works of John Stuart Mill (Toronto and Buffalo: Unjversity of Toronto Press, 1977), p. 292.

${ }^{6}$ Ibid., p. 223.

${ }^{7}$ Ibid., p. 224.

${ }^{8}$ Peter Singer, Practical Ethics (Cambridge: Cambridge University Press, 1979), pp. 112-113.

${ }^{9}$ The list of significant contributions to the liberationist debate is quite long. A few important examples would have to include: Peter Singer, Animal Liberation (New York: New York Review Books, 1975, 1990²); Stephen R. L. Clark, The Moral Status of Animals (Oxford: Oxford University Press,
1977); Tom Regan, The Case for Animal Rights (Berkeley: University of California Press, 1983); Steve F. Sapontzis, Morals, Reason and Animals (Philadelphia: Temple University Press, 1987); and James Rachels, Created from Animals: The Moral Implications of Darwinism (Oxford: Oxford University Press, 1990).

${ }^{10}$ See John Stuart Mill, Whewell on Moral Philosophy, quoted in Tom Regan and Peter Singer (eds.), Animal Rights and Human Obligations (Englewood Cliffs: Prentice-Hall, 1976), pp. 131-132.

${ }^{11}$ John Stuart Mill, op. cit., p. 285. My emphasis.

${ }^{12}$ William E. H. Lecky, History of European Morals (New York: George Braziller, 1985), p. 100-101. (First published: Longmans, London 1869.)

${ }^{13}$ Ibid., p. 271.

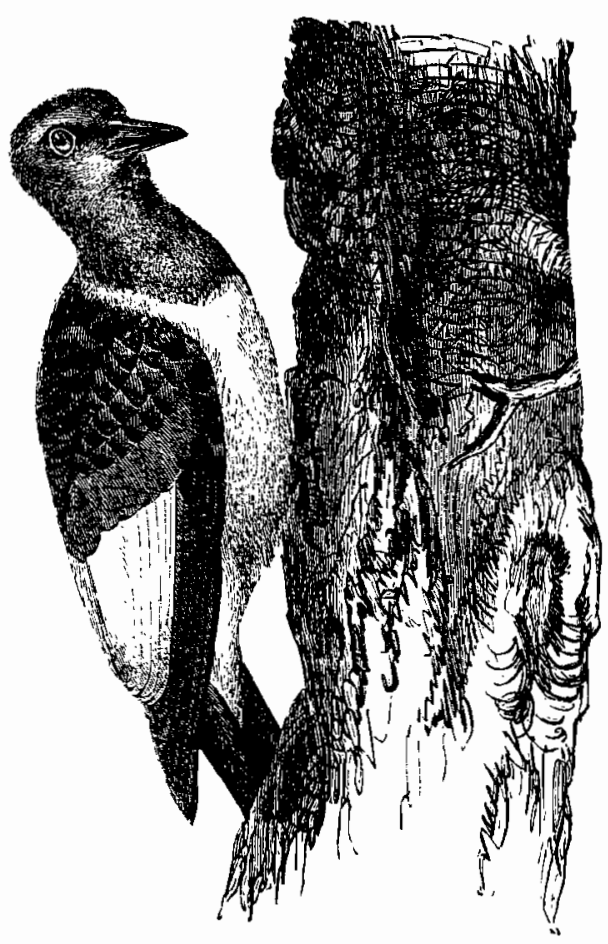

